\title{
SUMÁRIO / CONTENTS
}

\section{PENSAMENTO-ACONTECIMENTO: ALGUMAS INCURSÕES A PARTIR DA EXPERIÊNCIA DA LINGUAGEM \\ Event-thought: some incursions from the experience of language \\ Cintya Regina Ribeiro}

\section{UMA BREVE HISTÓRIA DO TEMPO NA LINGUAGEM}

A brief history of time in language

Heronides Moura

61 LINGUAGEM E ANALOGIA NO TIMEU DE PLATÃO

Language and analogy in Plato's Timaeus

Francisco de Assis Costa da Silva

81 NA HISTÓRIA DE UM GENTÍLICO, A TENSA INSCRIÇÃO DO OFÍCIO

In the history of a demonym the tension of inscribing the occupation

Alexandre Ferrari e Vanise Medeiros

107 AS MULHERES ENTRE O PODER E A RESISTÊNCIA: DISCURSO, HISTÓRIA E ACONTECIMENTO Women between power and resistance: speech, history and event Lúcia Helena Medeiros e Regina Baracuhy

123 O CRUZEIRO: ACONTECIMENTO E ROTINA COMO FORMA DE VIDA DA MULHER NOS ANOS 1950

$O$ Cruzeiro: happening and routine as a way of life of the woman at the fifties

Edna Maria Fernandes dos Santos Nascimento

147 NOS TRILHOS DA ESTRADA DE FERRO: REMINISCÊNCIAS DE MOTIVAÇÕES TOPONÍMICAS

$O n$ the rails of the iron road: reminiscences of toponymys motivations

Kênia Mara de Freitas Siqueira

171 UM ESTUDO TOPONÍMICO DE BONSUCESSO E PAI ANDRÉ NO RIO CUIABÁ-MT

A study of Bonsucesso toponymic and Pai André in Cuiabá river-MT

Elias Alves de Andrade e Marcilene Ribeiro da Silva 